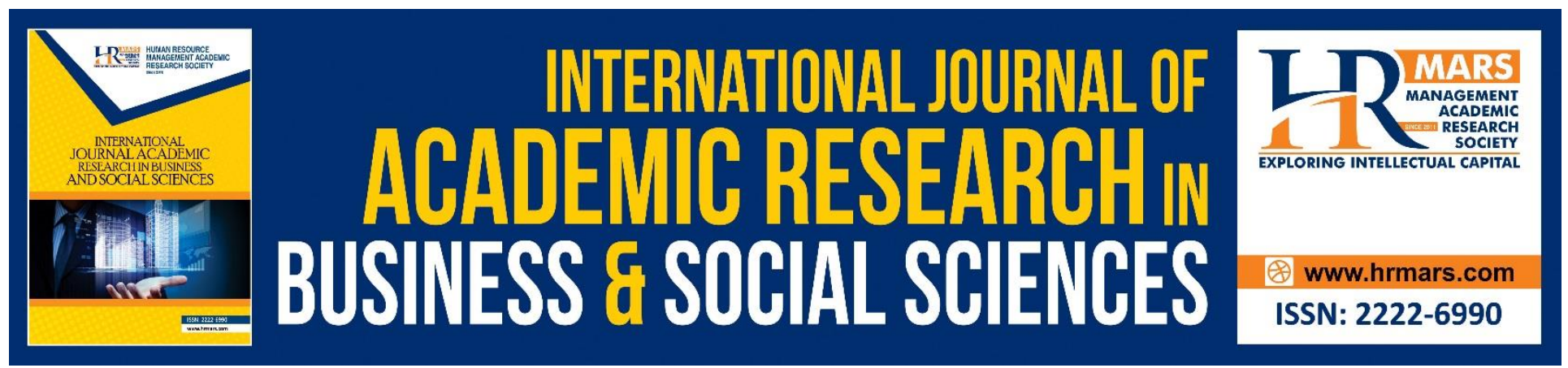

\title{
The Mediating Effects of Employee Competency on the Relationship between Training Functions and Employee Performance
}

Rahamah Mahmood, Ong Choon Hee, Ong Shze Yin, Mohd Syafiq Hanis Hamli

To Link this Article: http://dx.doi.org/10.6007/IJARBSS/v8-i7/4410

DOI: $\quad 10.6007 /$ IJARBSS/v8-i7/4410

Received: 20 May 2018, Revised: 19 June 2018, Accepted: 21 June 2018

Published Online: 12 July 2018

In-Text Citation: (Mahmood, Hee, Yin, \& Hamli, 2018)

To Cite this Article: Mahmood, R., Hee, O. C., Yin, O. S., \& Hamli, M. S. H. (2018). The Mediating Effects of Employee Competency on the Relationship between Training Functions and Employee Performance. International Journal of Academic Research in Business and Social Sciences, 8(7), 664-676.

Copyright: (C) 2018 The Author(s)

Published by Human Resource Management Academic Research Society (www.hrmars.com)

This article is published under the Creative Commons Attribution (CC BY 4.0) license. Anyone may reproduce, distribute, translate and create derivative works of this article (for both commercial and non-commercial purposes), subject to full attribution to the original publication and authors. The full terms of this license may be seen

at: http://creativecommons.org/licences/by/4.0/legalcode

Vol. 8, No. 7, July 2018, Pg. 664 - 676

http://hrmars.com/index.php/pages/detail/IJARBSS

JOURNAL HOMEPAGE

Full Terms \& Conditions of access and use can be found at http://hrmars.com/index.php/pages/detail/publication-ethics 


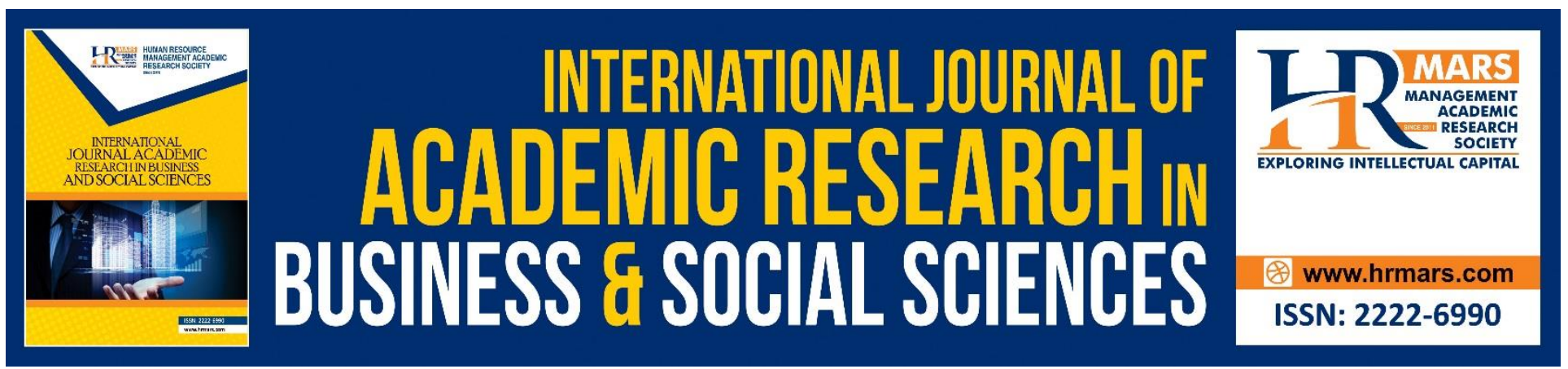

\title{
The Mediating Effects of Employee Competency on the Relationship between Training Functions and Employee Performance
}

\author{
Rahamah Mahmood, Ong Choon Hee, Ong Shze Yin, Mohd Syafiq \\ Hanis Hamli \\ Azman Hashim International Business School, Universiti Teknologi Malaysia, Johor, Malaysia. \\ Email: rahamah8170@gmail.com
}

\begin{abstract}
This paper aims to explain the relationship between training functions and employee performance and also to examine the mediating effects of employee competency on the relationship between training functions and employee performance. The training functions of this study were referred to training need analysis and training effectiveness. The respondents of this study consist of executives and assistant executives from a municipal council in Johor, Malaysia. A quantitative survey method was employed in this study coupled with factor analysis, descriptive analysis, correlation analysis and hierarchical regression analysis to analyse the collected data. The results show that training need analysis and training effectiveness were positively associated with employee performance. It was discovered that employee competency is a partial mediator between training functions and employee performance. The findings of this research will facilitate municipal councils and other local authorities in Malaysia to prioritize training need analysis and training effectiveness as part of the process in planning and implementing training programs since it has an impact on employee competency and employee performance.
\end{abstract}

Keywords: Employee Performance, Training Need Analysis, Training Effectiveness, Employee Competency.

\section{Introduction}

A local authority in Malaysia is responsible to provide municipal services to the stakeholders especially to the tax payers. The services delivered include providing and maintaining public amenities and infrastructures such as community hall, football field, playground, bus stand, wet market, hawker's centre, road, drainage, traffic light, lighting and landscape. Local authorities are also responsible to collect assessment tax and license fee, issue premise and business licenses, approve planning process, approve building plan, and to enforcing rules and regulations that are governed by the local authorities such as Act 171 of Local Government Act, Act 133 of Road, Drainage and Building Act and Act 172 of Town and Planning Act. Owing to globalisation and technology 
advancement, organizations are striving to be the best and the competition among them is intensifying as the world become borderless. In today's world, people are increasingly exposed to information technology and one of the impacts is that they become more knowledgeable and demanding. Hence, local authorities are facing more challenges in order to fulfil the stakeholders' needs and expectations. They are expected to provide excellent customer services to their customers. Employees are considered as an intellectual property in an organisation and the essential factor in surviving in the rapidly changing environment. Rationally, employee performance is related to their competency which could be gained through continuous training in accordance with the training needs that have been identified and gauged training effectiveness. Houger (2006) quoted that employee trainings were proven to be a valuable source of gaining competitive advantages and competencies. Organizations need to focus on planning and training development of its employees because it is important for them to understand and grow with the organization's vision and mission. Employees' achievements are the key component to accomplish organization objectives as it expands the viability and effectiveness of the organization. It equips employees to become future leaders that have all the required capacities, knowledge and abilities of a good leader (Elnaga and Imran, 2013). Thus, this research intends to examine the relationship between training need analysis, training effectiveness and employee performance and the mediating effects of employee competency towards the relationship between the study variables.

\section{Employee Performance}

Herbert, John \& Lee (2000) characterized employee performance as the result or commitment to achieve organizational objectives. Employee performance is one of the key elements to any effective organization. Its main goal is to achieve excellent employee's performance which will lead to an increase in effectiveness and subsequently generate tremendous effect on the efficiency of the organization. To achieve excellent performance, employees would be provided the skills and knowledge required to deliver high quality tasks and to prepare them for future top management positions. This will help organization to overcome any deficiencies in any job-related area (Elnaga and Imran, 2013). Hence, employee performance is vital for the success of any organization. Kenney et al. (1992) stated that employee's performance can be measured. It is able to be measured by comparing achievement against the targeted performance standard or goals set by the organization. According to Ahuja (2006), measurement of the performance can be based on several criteria such as productivity, efficiency, effectiveness, quality and profitability. Employee performance is considered excellent when productivity is achieving target set by the organization. Swart et al. (2005), described that training can be used as a tool to improve employee performance by eliminating skill deficits and reducing the performance gaps. A study of Nassazi (2013) proved that training positively influences employee performance through the development of knowledge, skills, ability and attitudes that were summarized as competency. Both employee and the organization will be benefited from the effects of training and competency towards their performance.

\section{Training Need Analysis}

Kaufman and Valentine (1999) defined Training need analysis (TNA) as a process where the organization analyses the cause of the performance gaps. TNA is the first process in designing training programs. The objective of TNA is to identify the needs of training from the employees in order to meet the organization targets and goals. TNA is used by most of the organizations to close the gaps between present knowledge, skills and attitudes and the desired knowledge, skills and attitudes in 
order to achieve effective employee performance (Landale, 1994). Therefore, TNA is a continuous process of information gathering to identify what types of training are needed by the employees to accomplish organization objectives. It is essential for organization to conduct needs assessment prior to conducting training program in order to curb the risk of implementing ineffective training programs that are not suitable for the employees or organizations. The accuracy of identifying training needs and the best way to fulfil the needs are the highest priority when designing training programs (Batram and Gibson, 2000). Organization should really focus on the steps of training cycle, for instance the identification of TNA, development of learning objectives before proposing, designing and implementing training programs. After the trainings were implemented, they should be re-evaluated by the organization to ensure its effectiveness is achieved (Biech, 2015). The program is considered successful if it is able to change the employee knowledge, skills or attitudes. Rossilah (2008) emphasized that TNA is a system which could alleviate the current performance gaps. Wamyayi et al. (2016) stated that TNA helps in maintaining the standard of employee performance. They further stated that TNA leads to acquisition of appropriate skills, curbs wastage of man hours and monetary resources. They concluded that TNA assists employees in gaining the right trainings which bridge the gap of inadequate trainings. It has been proven that the better the training, the better it can be translated into excellent performance. Therefore, based on the above discussion, it is hypothesized that:

H1: Training need analysis has a positive relationship with employee performance.

\section{Training Effectiveness}

Training effectiveness (TE) is one of the measurements of training outcome. According to Kirkpatrick (1994), evaluation of training programme is crucial to gauge the effectiveness of the training. Training effectiveness is about the extent of achieving goals or objectives of the training programme in terms of increasing knowledge, understanding, reactions, behaviour and performance. The level of effectiveness is determined by comparing situations before and after the training. Training effectiveness is vital to ensure organization would not spend time and money on training program that does not provide a good return. A well planned and systematic training program will result in enriching employees' competency that is required to perform work effectively. The aim is to provide individuals with information, skills and knowledge to carry out his duty competently. Drucker (1995) suggested that organization should look into various factors such as quality of product or service, organization profitability, employee motivation and efficiency, level of competency, smaller wastage and level of employee job satisfaction to improve training effectiveness. According to Wright \& Geroy (2001), effective training programs generally will improve skills, performance, motivation, efficiency and attitude of the employees. An effective training program that is delicately designed by the organization would hinder all the negative attributes such as dissatisfaction, complaints, and absenteeism. It will produce loyal employees and reduce turnover rate where employees were well trained and happily satisfied (Pigors \& Myers 1989). Training effectiveness is one of the measurement tools to close the gap of competency. Bently (1990) suggested that organizations must organize good training program via training road map so that it can help them to enhance employee knowledge, skills and attitude. A study of Falola et al. (2014), proved that training effectiveness has a strong relationship with employee performance. They elaborated that training effectiveness is important for effective performance in terms of employee adaptability towards change and challenging business environment and technology. Cole (2001) summarized that training effectiveness can boost 
INTERNATIONAL JOURNAL OF ACADEMIC RESEARCH IN BUSINESS AND SOCIAL SCIENCES

Vol. 8, No. 7, July 2018, E-ISSN: 2222-6990 @ 2018 HRMARS

employee morale, lower the cost of production, improve employee attendance, encourage positive involvement in organizational change, give recognition to employees and improve quality of the employees. Organizations ought to measure training effectiveness as it indicates the outcome of training translation to performance. Hence, based on the above discussion, it is hypothesized that:

H2: Training effectiveness has a positive relationship with employee performance.

\section{Employee Competency}

According to Boyatzis (2008), competency is an individual's capability or ability. However, Rossilah (2008) stated that competency or efficiency was referred to as a set of characteristics of knowledge, skills, attitudes, intellect and view of one's own interests to carry out their duties efficiently and effectively. McClelland (1998) further defined competency as basic personal characteristic that is a determining factor for acting successfully in a job or situation. It is important for an organization to ensure that employees have the knowledge, skills and attitude in accordance with the organization goals, objectives and values. Bently (1990) emphasized that in order for the employee to obtain all the needed competencies, organizations must develop a proper training program. There are five types of competency characteristics: Motives, traits, self-concept, knowledge and skills. All these characteristics were linked with superior performance in doing a job (Spencer and Spencer, 1993). Antwi (2015) recommended that competent employees in a high performance organization possess necessary skills, competency and ability to express their ideas. They will excel and perform to the fullest if they are offered favourable environment. The performance of the entire organization depends on its employee competencies. Employee competencies (EC) can be improved through effective training programs and subsequently enhance the employee overall performance. By gaining suitable knowledge, skills and attitude through training they can perform their current job more effectively and also prepare for future job (Wright \& Geroy, 2001). A study of Che Rusuli (2017) revealed that employee competency has mediating effect between human resource management function and service quality among workers in the hotel industry in Malaysia. Training is one of the functions in human resource development while employee performance is one of the indicators in service quality elements. The improvement in skills and knowledge will lead to superior service performance that may affect creativity, operational effectiveness and high-quality service delivery among frontline employees in the service industry. Blok (2009) stated that competencies are seen as the ultimate mediator between training interventions and performance of the job. Therefore, it is hypothesized that:

H3: Employee competency mediates the relationship between training need analysis and employee performance.

H4: Employee competency mediates the relationship between training effectiveness and employee performance.

\section{Methodology}

\section{Participants}

The targeted participants for this study were local municipal council employees. The samples included all executives who possessed Bachelor's degree as an entry level qualification and assistant executives who have a Diploma as an entry level qualification. Total population generated in this study was 112 . The participants were chosen because they involved in decision making and dealing 
INTERNATIONAL JOURNAL OF ACADEMIC RESEARCH IN BUSINESS AND SOCIAL SCIENCES

Vol. 8, No. 7, July 2018, E-ISSN: 2222-6990 @ 2018 HRMARS

directly with the public. They are the group of employees who have attended more training programs than other groups of employees.

\section{Method and Instruments}

This study is quantitative in nature which used survey as the research method. The sampling method was referred to the Krejcie and Morgan (1970) table whereby if the population is 112, the sampling size required would be 87 participants. The measures of employee performance were adapted from Ruzilla (2017). Measures for Training Need Analysis were adopted from Mohd Anuar et al (2015) and measures for training effectiveness were adopted from Abdullah Lin \& Mohd Yazam Sharif (2007) and Ashraf Mohammad Affandi (2016). Measures for employee competency were adopted from Ministry of Youth and Sports Malaysia (2017) and Kahirol et al (2014). Likert scale was used to measure all the study variables. The scale was anchored by 1 (Strongly disagree), 2 (Disagree), 3 (Neutral), 4 (Agree) and 5 (Strongly agree).

\section{Data Analysis}

Data analysis in the present study was conducted using Statistical Package for Social Science (SPSS). Factor analysis was selected to test the validity of the constructs and to assess how well the results obtained from the use of the measures represented the concept being measured (Sekaran and Bougie, 2010). Separately, linear regression analysis was used to examine the relationship between training functions and employee performance while hierarchical regression was used to examine the mediating effects of employee competency on the relationship between training functions and employee performance.

\section{Results}

\section{Profile of the Respondents}

The questionnaires were distributed via hard copy which targeted to reach 112 participants who are executives and assistant executives of the local municipal council, but only 107 responses were obtained which represent $95.5 \%$ of the response rate. In this research, the researcher has also gathered dataset of personal characteristics such as gender, length of service, age and level of education. From the responses the researcher received, 59 were male respondents and 48 were females. Majority of the respondents ( 54 or $50.5 \%$ ) have worked with the municipal council between 5 to 10 years. Respondents aged above 41 years old were 36, aged between 31 to 40 were 46, aged from 26-30 were 22 and there were 3 respondents aged less than 25 years old. For the level of education, majority of the respondents (63 or 58.9\%) possessed a diploma as their entry level of qualification. This is followed by respondents with bachelor's degree (31.8\%) and master's degree (9.3\%). Therefore, majority of the respondents were assistant executives who constituted most number of employees in the municipal council.

\section{Factor Analysis}

The independent and dependent variables were validated using factor analysis. Table 1 depicts the results of Kaiser-Meyer-Olkin (KMO) and Bartlett's Test for the study variables. The values of KaiserMeyer-Olkin for Measuring of Sampling Adequacy (KMO/MSA) were 0.812, 0.886 and 0.814 for training functions, employee performance and employee competency. All the KMO values had reached the minimum value of 0.6 for a good factor analysis (Hair et, 2010). The Bartlett's Test of 
INTERNATIONAL JOURNAL OF ACADEMIC RESEARCH IN BUSINESS AND SOCIAL SCIENCES

Vol. 8, No. 7, July 2018, E-ISSN: 2222-6990 (C) 2018 HRMARS

Sphericity was statistically significant $(p<0.001)$, thus supported the factorability of the correlation matrix.

\section{Training Functions}

The principal component analysis (PCA) with varimax rotation extracted five (5) items for component 1 (TE) and four (4) items for component 2 (TNA) after cross loadings were deleted and factor loading of 0.5 and below were discarded. The rotated factors captured a total of $57.805 \%$ of the variance in which component 1 contributes 43.262\%, followed by component 2 at $14.543 \%$. Drawing on the factor analysis results (see Table 2), items that loaded on component 1 (5 items) were labelled as training effectiveness (TE), and component 2 ( 4 items) was named training need analysis (TNA).

Table 1: Kaiser-Meyer-Olkin (KMO) and Bartlett's Test for Training Functions

\begin{tabular}{ccccc}
\hline \multicolumn{2}{c}{ Factorability Assessment } & $\begin{array}{c}\text { Training } \\
\text { Functions }\end{array}$ & $\begin{array}{c}\text { Employee } \\
\text { Performance }\end{array}$ & $\begin{array}{c}\text { Employee } \\
\text { Competency }\end{array}$ \\
\hline Kaiser-Meyer-Olkin Measure of Sampling & 0.812 & 0.886 & 0.814 \\
Adequacy & Approx. Chi-Square & 414.974 & 682.329 & 275.922 \\
\hline \multirow{2}{*}{$\begin{array}{c}\text { Bartlett's Test } \\
\text { of Sphericity }\end{array}$} & $\mathrm{df}$ & 45 & 45 & 15 \\
\cline { 2 - 5 } & Sig. & .000 & .000 & .000 \\
\hline
\end{tabular}

Table 2. Factor Analysis for Training Functions

\begin{tabular}{ccc}
\hline Items & Factor Loading & Factor Loading \\
& 1 & 2 \\
\hline B1 & & 0.670 \\
B2 & & 0.805 \\
B3 & & 0.802 \\
B4 & & 0.784 \\
C1 & .805 & \\
C2 & .765 & \\
C3 & .676 & \\
C7 & .743 & \\
C8 & .711 & \\
Eigenvalues & 4.326 & 1.454 \\
Percentage of Common variance & 43.262 & 14.543 \\
Cumulative $\%$ & 43.262 & 57.805 \\
Reliability Coefficient $(\alpha)$ & 0.765 & 0.828 \\
\hline
\end{tabular}

\section{Employee Competency}

The principal component analysis (PCA) extracted 6 items that captured a total variance of 58.066\% with an Eigenvalue of 3.484. The values of factor loading for employee competency were in the range of 0.717 to 0.793 whereas those factor loadings below 0.50 were discarded and cross loadings were 
INTERNATIONAL JOURNAL OF ACADEMIC RESEARCH IN BUSINESS AND SOCIAL SCIENCES

Vol. 8, No. 7, July 2018, E-ISSN: 2222-6990 @ 2018 HRMARS

deleted during the factor analysis. All the 6 items were loaded on a single factor and labelled as employee performance. The results of the factor analysis were displayed in Table 3.

Table 3. Factor Analysis for Employee Competency

\begin{tabular}{cc}
\hline Items & Factor Loading 1 \\
\hline D6 & 0.760 \\
D7 & 0.717 \\
D8 & 0.751 \\
D12 & 0.793 \\
D13 & 0.767 \\
D14 & 0.782 \\
\hline Eigenvalues & 3.484 \\
Percentage of Common variance & 58.066 \\
Cumulative \% & 58.066 \\
Reliability Coefficient $(\alpha)$ & 0.854 \\
\hline
\end{tabular}

\section{Employee Performance}

The principal component analysis (PCA) extracted 10 items that captured a total variance of $60.725 \%$ with an Eigenvalue of 6.072. The values of factor loading for employee performance were in the range of 0.706 to 0.847 . All the 10 items were loaded on a single factor and labelled as employee performance. The results of the factor analysis were displayed in Table 4.

Table 4. Factor Analysis for Employee Performance

\begin{tabular}{cc}
\hline Items & Factor Loading 1 \\
\hline E1 & 0.717 \\
E2 & 0.760 \\
E3 & 0.808 \\
E4 & 0.809 \\
E5 & 0.795 \\
E6 & 0.847 \\
E7 & 0.811 \\
E8 & 0.780 \\
E9 & 0.706 \\
E10 & 0.748 \\
\hline Eigenvalues & 6.072 \\
Cumulative $\%$ & 60.725 \\
Rercentage of Common variance & 60.725 \\
\end{tabular}

\section{Reliability Test}

The reliability coefficient (Cronbach's Alpha) for the independent variables namely training need analysis and training effectiveness was rated 0.765 , and 0.828 respectively. Cronbach's Alpha value for the mediating variable, employee competency was 0.854 while dependent variable, employee 
INTERNATIONAL JOURNAL OF ACADEMIC RESEARCH IN BUSINESS AND SOCIAL SCIENCES

Vol. 8, No. 7, July 2018, E-ISSN: 2222-6990 @ 2018 HRMARS

performance was 0.926. All the measures were deemed reliable and consistent throughout the study as all values have exceeded the minimum value of 0.7 as suggested by George and Mallery (2003). These statistical results confirmed the reliability of measurement scales used for this study.

\section{Correlational Analysis}

Correlation analysis was conducted in this study to investigate the association between the study variables. Table 5 shows the correlation between four variables. From the table, it was revealed that the relationship between employee competency (EC) and employee performance (EP) is high $(r=0.677)$ and the correlation coefficient is significant at the $p<0.01$ level. Other the other hand, the relationship between training need analysis (TNA) and training effectiveness (TE) was found to be moderately high $(r=0.533)$. There is also a positive relationship between training effectiveness and employee performance $(r=0.505, p<0.01)$. The relationship between employee performance and training need analysis shows a moderate and positive relationship ( $r=0.469, p<0.01)$. In summary, correlation analysis indicates significant association between the study variables and it is deemed suitable to proceed with regression analysis.

Table 5: Correlation Analysis

\begin{tabular}{|c|c|c|c|c|}
\hline Variables & $\begin{array}{c}\text { Training Need } \\
\text { Analysis } \\
\end{array}$ & $\begin{array}{c}\text { Training } \\
\text { Effectiveness }\end{array}$ & $\begin{array}{c}\text { Employee } \\
\text { Competency }\end{array}$ & $\begin{array}{c}\text { Employee } \\
\text { Performance }\end{array}$ \\
\hline $\begin{array}{c}\text { Training Need } \\
\text { Analysis }\end{array}$ & 1 & & & \\
\hline $\begin{array}{c}\text { Training } \\
\text { Effectiveness }\end{array}$ & $.533^{* *}$ & 1 & & \\
\hline $\begin{array}{c}\text { Employee } \\
\text { Competency }\end{array}$ & $.398 * *$ & $.431 * *$ & 1 & \\
\hline $\begin{array}{c}\text { Employee } \\
\text { Performance }\end{array}$ & $.469 * *$ & $.505^{* *}$ & $677^{* *}$ & 1 \\
\hline
\end{tabular}

\section{Regression Analysis}

Table 6 shows the linear regression analysis results among the independent variables and employee performance. The analysis indicates that $22.0 \%(R 2=0.220)$ of the variance of employee performance can be explained by the two independent variables of training functions. The analysis shows that TNA $(\beta=0.469, p<0.001)$ and TE $(\beta=0.505, p<0.001)$ have a significant positive relationship with EP. Therefore, $\mathrm{H} 1$ and $\mathrm{H} 2$ were accepted. Table 7 and 8 shows the hierarchical regression analysis results for the mediating effects. It was discovered that $E C(\beta=0.583, p<0.001)$ partially mediates the relationship between TNA and EP where TNA was still significantly associated with EP $(\beta=0.237, p<0.001)$ however its standardized coefficient has been reduced from 0.439 to 0.237 and $R 2$ increased from 0.220 to 0.505 . Thus, $H 3$ was supported. On the other hand, $E C(\beta=0.564, p<0.001)$ was found also partially mediates the relationship between TE and EP, whereby TE was still significantly associated with EP $(\beta=0.262, p<0.001)$ however its standardized coefficient has been reduced from 0.505 to 0.262 and $\mathrm{R} 2$ increased from 0.255 to 0.514 . Thus, H4 was supported. 
INTERNATIONAL JOURNAL OF ACADEMIC RESEARCH IN BUSINESS AND SOCIAL SCIENCES Vol. 8, No. 7, July 2018, E-ISSN: 2222-6990 @ 2018 HRMARS

Table 6: Linear Regression Analysis between Independent Variable and Employee Performance

\begin{tabular}{|c|c|c|c|c|c|c|}
\hline \multirow{2}{*}{$\begin{array}{c}\text { Independent } \\
\text { Variable }\end{array}$} & \multicolumn{4}{|c|}{ Employee Performance } & \multirow{2}{*}{ Hypothesis } & \multirow{2}{*}{ Result } \\
\hline & beta, $\beta$ & Sig. & $\mathrm{R}$ & $\mathrm{R}^{2}$ & & \\
\hline $\begin{array}{c}\text { Training Need } \\
\text { Analysis } \\
\end{array}$ & $0.469 * * *$ & 0.000 & 0.469 & 0.220 & $\mathrm{H} 1$ & Accepted \\
\hline $\begin{array}{c}\text { Training } \\
\text { Effectiveness }\end{array}$ & $0.505^{* * *}$ & 0.000 & 0.5055 & 0.255 & $\mathrm{H} 2$ & Accepted \\
\hline
\end{tabular}

*** Significant at the 0.001 level, ** Significant at the 0.01 level

Table 7: Hierarchical Regression Analysis for Employee Competency mediates Training Need Analysis and Employee Performance

\begin{tabular}{|c|c|c|c|c|c|c|}
\hline \multirow{2}{*}{ Variable } & \multicolumn{4}{|c|}{ Employee Performance } & \multirow{2}{*}{ Hypothesis } & \multirow{2}{*}{ Result } \\
\hline & beta, $\beta$ & Sig. & $\mathrm{R}^{2}(\mathrm{TNA})$ & $\mathrm{R}^{2}(\mathrm{TNA} \& E C)$ & & \\
\hline $\begin{array}{c}\text { Training Need } \\
\text { Analysis }\end{array}$ & $0.237 * * *$ & 0.000 & 0.220 & 0.505 & $\mathrm{H3}$ & Accepted \\
\hline $\begin{array}{l}\text { Employee } \\
\text { Competency }\end{array}$ & $0.583 * * *$ & & & & & \\
\hline
\end{tabular}

Table 8: Hierarchical Regression Analysis for Employee Competency mediates Training Effectiveness and Employee Performance

\begin{tabular}{|c|c|c|c|c|c|c|}
\hline \multirow{2}{*}{ Variable } & \multicolumn{4}{|c|}{ Employee Performance } & \multirow{2}{*}{ Hypothesis } & \multirow{2}{*}{ Result } \\
\hline & beta, $\beta$ & Sig. & $\mathrm{R}^{2}(\mathrm{TE})$ & $\mathrm{R}^{2}(T E \& E C)$ & & \\
\hline $\begin{array}{c}\text { Training } \\
\text { Effectiveness }\end{array}$ & $0.262 * * *$ & 0.000 & 0.255 & 0.514 & $\mathrm{H} 4$ & Accepted \\
\hline $\begin{array}{c}\text { Employee } \\
\text { Competency }\end{array}$ & $0.564 * * *$ & & & & & \\
\hline
\end{tabular}

\section{Discussion}

From the findings, it can be discovered that the implementation of TNA as the first step of any training process in one's organization is imperative. By implementing TNA, the organization may identify the most needed trainings and workshops thus avoid conducting those that are not needed. With TNA, an organization is able to prioritize the effective parts of training for the employees. The process of identifying training needs in an organization enhances and upgrades employee performance and productivity. This finding is in line with a study of Wamyayi et al. (2016), who stated that TNA assists in maintaining the standard of employee performance. They further elaborated that TNA leads to acquisition of appropriate skills, curbs wastage of man hours and monetary resources. They concluded that TNA leads to help employees attending the right training and bridge the gap between deficiency and efficiency. Apart from that, the finding of this study also indicates that training effectiveness has a positive relationship with employee performance. Cole (2001) concurred that training effectiveness can improve employee performance in terms of boosting employee morale, 
lowering the cost of production, improving employee attendance, encouraging positive involvement in organization change, providing recognition to employees and increasing quality of the employee performance. Nassazi (2013) in her study on effects of training on employee performance, found that training effectiveness was proven to have an impact on the performance of employees in relation to their jobs. In addition, Falola (2014) also proved that training effectiveness has a strong relationship with employee performance. He further described that training effectiveness is important for effective performance in terms of employee adaptability towards change and challenging business environment. Besides, It is also important in increasing employees' knowledge to develop critical thinking and problem-solving skills. Therefore, it is crucial to ensure that training effectiveness will be measured after the training was provided to the staffs. In examining the mediating effects of employee competency on the relationship between training need analysis (TNA) and employee performance, the result shows that employee competency is a partial mediator for employee performance and training need analysis. However, there was not much research conducted on the mediating role of employee competency. This is probably due to the reason that most researchers focus on general trainings or human resource management functions instead of TNA. For example, a study of Che Rusuli (2017) revealed that employee competency mediates the relationship between training as part of human resource management functions and service performance where one of the indicators is employee performance. On the other hand, the mediating effect of employee competency was found to be significant on the relationship between training effectiveness and employee performance. This finding is consistent with a study of Blok (2009) where it was discovered that employee competency partially mediates the relationship between training and critical behavior of the employee performance. In a nutshell, organizations should focus more on training need analysis, training effectiveness and employee competency as they pose great impacts towards employee performance.

\section{Limitations and Future Study}

This research was conducted under certain limitations that have to be taken into consideration. The research was conducted in one of the local municipal councils in Johor, Malaysia. The results may not able to generalize for the other local authorities in Malaysia. As such, it is suggested that future research may expand the study population and establish a broader research setting where it may cover all local authorities in the state of Johor and explore more factors that may influence employee competency and employee performance of the local authorities.

\section{Conclusion}

The findings show that training functions are significantly related to employee performance and employee competency is partially mediating the relationship between training functions and employee performance. Therefore, it is important for any organizations to provide a proper training need analysis and training effectiveness evaluation for their employees in order to produce competent and high-performing employees. By having a systematic training procedures, it will assist municipal council employees to increase their competencies in handling day-to-day activities and providing excellent customer service to the public. With excellent community service, it is expected that the public complaints will be reduced. 
INTERNATIONAL JOURNAL OF ACADEMIC RESEARCH IN BUSINESS AND SOCIAL SCIENCES

Vol. 8, No. 7, July 2018, E-ISSN: 2222-6990 @ 2018 HRMARS

\section{Acknowledgements}

The authors would like to thank the Malaysian Ministry of Higher Education and Universiti Teknologi Malaysia (GUP-Vot: 14J81) for providing financial support to publish this paper.

\section{References}

Abdullah, L., \& Mohd, Y. S. (2007). Factors affecting training effectiveness. A study of semiconductor wafer fabrication industry in Malaysia, College of Business Universiti Utara Malaysia.

Ahuja, K. (2006). A handbook of personnel management practices. Kogan Page Limited London.

Antwi, J. O. \& Owusu, A. (2015). Employee's competency and organizational performance in the pharmaceutical industry an empirical study of pharmaceutical firms in Ghana, International Journal of Economics, Commerce and Management United Kingdom, III(3), March 2015.

Ashraf, M. A. (2016). Training impact on the performance of employees: A case of Jordanian travel and tourism institutions, International Business Management, Medwell Journals.

Batram, S. \& Gibson. (2000). The Training Needs Analysts, SBG Associates.

Bently, T. (1990). Training - Investing in the future, Industrial Management and Data System, 10 -17 Biech, E. (2015). Training and Development for Dummies, ebook.

Blok, M.S. (2009). The mediating role of competencies in training effectiveness, Master's Thesis, University of Twente, Enschede, the Netherlands.

Boyatziz, R. E. (2008). Competencies in the 21st centuries, Journal of Management Development, 27(1), 5-12

Che Rusuli, M. S. (2017). The mediating effect of employee competencies on the relationship between human resource development practice and service performance among front line employees in hotel industries. International Journal of Applied Business and Economic Research, 15(22).

Cole, K. (2001). Supervision: The theory and practise of first-line management $-2^{\text {nd }}$ edition, Frenchs Forest, NSW Prentice Hall.

Drucker, P. F. (1995). Managing In a Time of Great Change. New York, NY: Truman Talley.

Elnaga, A., \& Imran, A. (2013). The effect of training on employee performance. Eur. J. Business Management, 5: $137-147$

Falola H.O., Osibanjo, A.O., \& Ojo, S.I. (2014). Effectiveness of training and development on employees' performance and organisation competitiveness in the Nigerian banking industry, Bulletin of the Transilvania University of Braşov Series V: Economic Sciences, 7(56) No. 1- 2014.

George, D., Mallery, P. (2003). SPSS for Windows step by step: A simple guide and reference (4 ${ }^{\text {th }}$ ed.) Boston: MA: Allyn\& Bacon

Hair, J. F., Black, W.C., Babin, B. J., \& Anderson, R.E. (2010). Multivariate Data Analysis. (7 ${ }^{\text {th }}$ ed.) New Jersey, Prentice Hall.

Houger, V. P., (2006), Trends of employees performance: Collaborative efforts between manager and employees, Journal of Performance Improvement, 45(5), 26-31.

Kanungo, R.N. (1982). Measurement of job and work involvement, Journal of Applied Psychology, 77, 341-349.

Kirkpatrick, D. L. (1994). Evaluating Training Programs: The Four Levels. San Francisco: BerrettKoehler.

Kaufman, R., \& Valentine, G. (1999). Relating needs assessment and needs analysis. Performance and Instruction, 28(10), 10-14. 
INTERNATIONAL JOURNAL OF ACADEMIC RESEARCH IN BUSINESS AND SOCIAL SCIENCES

Vol. 8, No. 7, July 2018, E-ISSN: 2222-6990 @ 2018 HRMARS

Krejcie, R. V., \& Morgan, D. W. (1970), Determining sample size for research activities, Educational and Psychological Measurement, 30, 607-610.

Landale, A. (1994). Gower Handbook of Training \& Development. Gower in Association with the Institute of Training \& Management.

McLelland, D.C. (1998). Identifying competencies with behavioral event interviews. Psychological Science, 9(5), $331-339$.

Ministry of Youth and Sports Malaysia, (2017). Kompetensi Kumpulan Pengurusan dan Profesional, http://interaktif.kbs.gov.my/pengurusan/value.php.

Nassazi, A. (2013). Effects of training on employee performance: Evidence from Uganda, Business Economics and Tourism, Vaasan Ammattikorkeakoulu University of Applied Sciences.

Rossilah, J. (2008). Analisis Kepeluan Latihan Teori dan Praktis, Edisi Pertama, Universiti Teknologi Malaysia.

Ruzilla, I. (2017). The Relationship between Perceived Leadership Styles and Employee Performances: The Mediating Role of Employee Engagement in IRBM Johor Bahru, Thesis submitted to Universiti Teknology Malaysia.

Sekaran, U. \& Bougie, R. (2010). Research Methods for Business: A Skill Building Approach, United Kingdom: Wiley.

Spencer, L. M., \& Spencer, S. M. (1993). Competence at work: Models for superior performance. New York: Wiley.

Wright, P. \& Geroy, D. G. (2001). Changing the mindset: the training myth and the need for wordclass performance. International Journal of Human Resource Management, 12(4), 586-600. 